\title{
Importance of Sodium Levels for Geriatric Patients Presented to the Emergency Department with a Simple Fall
}

\author{
Acil Servise Basit Düșme Şikayetiyle Gelen Geriatrik Hastalarda \\ Sodyum Seviyesinin Önemi
}

\author{
Tolga Öz', Ayhan Özhasenekler², Gül Pamukçu Günaydın', Yavuz Otal', Gülhan Kurtoğlu Çelik², \\ Selçuk Çoşkun' ${ }^{1}$ Fatih Tanrıverdi², Şervan Gökhan²
}

\begin{abstract}
${ }^{1}$ Ankara Atatürk Education and Research Hospital, Emergency Department
${ }^{2}$ Ankara Yıldırım Beyazıt University, Medical Faculty, Emergency Department
\end{abstract}

\begin{abstract}
Objectives: The aim of this study is to investigate the effect of plasma sodium concentration on falls in geriatric patients age of $\geq 65$ years who visited the emergency room for simple falls.

Materials and Methods: The ages and genders of the patients, plasma sodium values at presentation, localizations of the injuries, radiological examination results (radiography and computed tomography), classification of the injury, the presence of accompanying fractures and whether the patient had been referred from a nursing home were recorded and injuries were compared according to sodium levels. Results: There was no statistically significant difference between the location of the injuries and the presence of hyponatremia $(\mathrm{p}=\mathrm{0} .743)$. The prevalence of hyponatremia was statistically significant in the patients who were referred from a nursing home for simple falls $(\mathrm{p}<0.001)$. The increase in the incidence of vertebral and pelvic injuries as hyponatremia became more severe was statistically significant

( $\mathrm{p}<0.001)$.

Conclusion: Hyponatremia should be considered as an independent risk factor for falls in patients who are $\geq 65$ years. Hyponatremia is more common in the patients who are staying in nursing homes. In our study, no direct relationship between hyponatremia and fracture formation has been detected.

Key words: Accidental falls, geriatric assessment, hyponatremia
\end{abstract}

\section{Öz}

Amaç: Bu çalışmanın amacı acil servise basit düşme nedeniyle başvuran 65 yaş ve üstü hastalarda serum sodyum değeri ile düşme ilișkisini belirlemektir.

Materyal ve Metot: Hastaların yaşları, cinsiyetleri, gelișteki sodyum değerleri, yaralanma bölgeleri, radyolojik inceleme sonuçları (düz grafi ve tomografi), yaralanmanın sınıflaması, eșlik eden kırık varlığı ve hastanın bakım evinden gelip gelmediği kaydedildi ve yaralanmalar sodyum seviyelerine göre karşılaştırıldı.

Bulgular: Yaralanma bölgeleri ile hiponatremi varlığı arasında anlamlı farklılık tespit edilmedi. $(\mathrm{p}=\mathrm{o}, 743)$. Basit düşme ile bakımevinden gelen hastalarda hiponatremi prevalansı, bakımevinden gelmeyen hastalara göre istatistiksel olarak anlamlı derecede yüksek bulundu ( $\mathrm{p}<\mathrm{o}, \mathrm{ool})$. Hiponatremi derinleștikçe vertebra ve pelvis yaralanmalarında anlamlı artış görüldü ( $\mathrm{p}<0,001)$.

Sonuç: Acil servise basit düşmeyle gelen 65 yaș ve üstü hastalarda, hiponatremi düşme için bir risk faktörü olarak göz önüne alınmalıdır. Bakımevlerinde yaşayan kişilerde hiponatremi diğer hastalara göre daha sık görülmektedir. Çalışmamızda hiponatremi ile kırık oluşumu arasında doğrudan bir ilişsi saptanamamıștır.

Anahtar kelimeler: Kaza ile düșme, geriatrik değerlendirme, hiponatremi

\section{Correspondence / Yazışma Adresi:}

Dr. Gülhan Kurtoğlu Çelik

Ankara Yıldırım Beyazıt University, Medical Faculty, Emergency Department, Bilkent / Ankara

e-mail: kurtoglugulhan@yahoo.com

Date of submission: 04.07.2018

Date of admission: 21.11.2018 
Importance of Sodium Levels for Geriatric Patients Presented to the Emergency Department with a Simple Fall

\section{Introduction}

Every year, approximately one-third of patients at the age of $\geq 65$ years are exposed to fall-related traumas, which account for a substantial proportion of geriatric traumatic injuries. Fall-related trauma poses additional financial burdens to the health system by restricting the patients' abilities to move independently, decreases quality of life, increases the prevalence and incidence of comorbid conditions, and leads to the need for care at home or at a nursing house. ${ }^{1,2}$ Obviously identification of risk factors of falls in high-risk patients is necessary for the prevention of falls and potential future fractures in the emergency department..$^{3-5}$

Previous studies stated that sodium $\left(\mathrm{Na}^{+}\right)$disorders are common in the elderly and that hyponatremia in particular might be the cause of falls as it leads to confusion and delirium. ${ }^{1,6-8}$ Mild hyponatremia is frequently encountered in laboratory tests performed with geriatric subjects with no significant health problems and, considering that falls are common in geriatric patients, the relation seems worth investigation. ${ }^{1}$

In the present study, we investigated the effect of plasma $\mathrm{Na}^{+}$concentration on falls in geriatric patients age of $\geq 65$ years who visited the emergency department for simple falls.

\section{Materials and Methods}

This is a prospective, observational study. Data from patients who visited Ankara Atatürk Training and Research Hospital Emergency Department between 01.11.2014 and 01.06.2015 for simple falls were analyzed. Study protocol was approved by the Ankara Atatürk Training and Research Hospital Local Ethics Committee. The ages and genders of the patients, plasma $\mathrm{Na}^{+}$values at presentation, localizations of the injuries, radiological examination results (radiography and computed tomography), classification of the injury, the presence of accompanying fractures, and whether the patient had been referred from a nursing home were recorded on a study form. The patients were divided into three age groups according to the recommendations of the guidelines released by the American Geriatrics Society (AGS) and the Geriatric Emergencies Department of the World Health Organization (WHO)as young-old (6574), middle-old (75-84) and oldest-old (85 and older)., 9

The patients were divided into subgroups based on plasma $\mathrm{Na}^{+}$concentrations as follows: normonatremia (135-145 mmol/L), mild hyponatremia (130-134 mmol/L), moderate hyponatremia (125-129 mmol/L), and severe hyponatremia $(<125 \mathrm{mmol} / \mathrm{L}) .^{10-12}$

\section{The inclusion criteria were as follows:}

- Patients $\geq 65$ years,

- Presented to the emergency department with a simple fall or fall from a height less than $1 \mathrm{~m}$,

- Biochemical parameters including the plasma $\mathrm{Na}^{+}$concentration were measured at presentation,

- Radiological examinations of the location of the injury (radiography or computed tomography) are available, 
Importance of Sodium Levels for Geriatric Patients Presented to the Emergency Department with a Simple Fall

- Injury localization and presence of accompanying fracture were clearly explained by the physician who performed the initial examination,

- Agreed to participate in the study

\section{The exclusion criteria were as follows:}

- Under the age of 65 years,

- Presented to the emergency department with any reason other than a simple fall,

- Laboratory parameters were not measured,

- Injury or fractures not clearly explained in the research form,

- Did not agree to participate in the study

\section{Statistical analysis}

The data were analyzed using the Statistical Package for Social Sciences (SPSS) for Windows (IBM Corp. Released 2011. IBM SPSS Version 20.0. Armonk, NY:IBM Corp).The comparisons of the age groups between the genders, the relationships of hyponatremia with the age groups and genders, the presences of fractures and hyponatremia in the patients from the nursing homes were analyzed with chi-square tests, and comparisons of the presence and degree of hyponatremia between the age groups were performed with one-way analysis of variance (ANOVA). The level of significance for the results was set at $\mathrm{p}<0.05$.

\section{Results}

In the study, 269 patients who met the eligibility criteria were included. Of the patients, $62.45 \%(\mathrm{n}=168)$ were female $(\mathrm{F}), 37.54 \%(\mathrm{n}=101)$ were male $(\mathrm{M})$, and the mean age was $79.20 \pm 8.08$ years. The mean age of male was $80.02 \pm 7.93$ years, females was $78.15 \pm 8.28$ years. There was no statistically significant difference between the females and males in terms of mean age $(\mathrm{p}=0.052)$. There were no significant differences between the age groups $(65-7436 \mathrm{M}, 47 \mathrm{~F} ; 75-8437 \mathrm{M}, 60 \mathrm{~F} ; \geq 8528 \mathrm{M}, 61 \mathrm{~F})$ in terms of the distributions of genders $(\mathrm{p}=0.269)$.

Among the patients, $28.25 \%(\mathrm{n}=76)$ were hyponatremic, 69.88\% ( $\mathrm{n}=188)$ were normonatremic, and $1.85 \%(\mathrm{n}=5)$ were hypernatremic.

Evaluating of the hyponatremic patients according to age group revealed a statistically significant difference between the age groups in terms of the prevalence of hyponatremia ( $\mathrm{p}=0.042$, Table 1 ). There was no statistically significant difference between genders in terms of prevalence of hyponatremia $(\mathrm{p}=0.682)$.

Table 1. Hyponatremic Patients According to Age Groups

\begin{tabular}{|l|c|c|c|}
\hline \multirow{2}{*}{ Age Groups } & \multicolumn{2}{|c|}{ Hyponatremia } & \multirow{2}{*}{$\mathbf{p}$} \\
\cline { 2 - 3 } & Negative n (\%) & Positive n (\%) & \\
\hline $\mathbf{6 5} \mathbf{- 7 4}$ & $53(27.46)$ & $30(39.47)$ & \multirow{2}{*}{$0.042^{*}$} \\
\hline $\mathbf{7 5 - 8 4}$ & $68(35.23)$ & $29(38.15)$ & \\
\hline$\geq \mathbf{8 5}$ & $72(37.30)$ & $17(22.36)$ & \\
\hline
\end{tabular}


Importance of Sodium Levels for Geriatric Patients Presented to the Emergency Department with a Simple Fall

There were no statistically significant differences in the locations of the injuries according to the presence of hyponatremia $(\mathrm{p}=\mathrm{o} .743)$. The prevalence of hyponatremia was not significantly different between the patients with and without fractures (p=0.105; OR: o.643; CI: 0.377 - 1.098) (Table 2).

Table 2. Evaluation of the patients according to the locations of the injuries, the presence of fracture and according to referrals from nursing homes

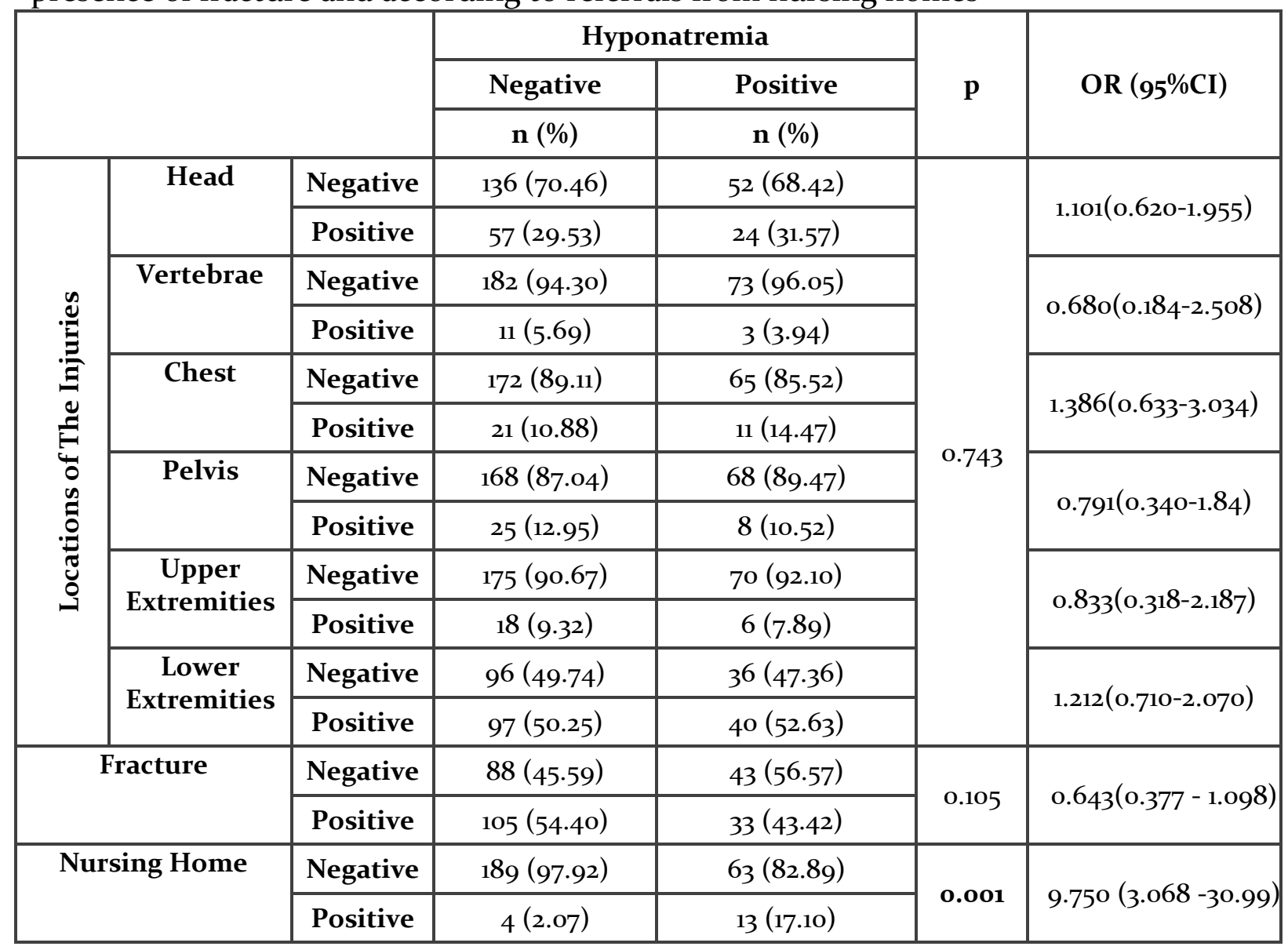

In the study population there was $138(51.30 \%)$ total fractures was seen. Of those fractures, $81(58.69 \%)$ was femur fractures, followed by fractures of the humerus $(5.79 \%, n=8)$, pelvic belt $(5,79 \%, n=8)$, vertebrae $(4,34 \%, n=6)$, bones in the head region $(3.62 \%, \mathrm{n}=5)$, costae $(2.89 \%, \mathrm{n}=4)$, radius $(1.44 \%, \mathrm{n}=2)$ and other fractures $(17.39 \%, \mathrm{n}=24)$.

In the study $6.31 \%(\mathrm{n}=17)$ patients were referred from a nursing home. Hyponatremia was detected in $76.47 \%(\mathrm{n}=13)$ of these patients. The prevalence of hyponatremia was statistically significant in the patients who were referred from a nursing home for simple falls (p<0.001; OR: 9.750; CI: 3.068 -30.99) (Table 2).

When hyponatremic patients were divided in three groups according to Na value as severe $(\mathrm{Na}<125)$, moderate $(125 \leq \mathrm{Na} \leq 129)$ and mild $(130 \leq \mathrm{Na}<135)$ and locations of injuries was compared between groups the increase in the incidence of vertebral and pelvic injuries as hyponatremia became more severe was statistically significant ( $\mathrm{p}<0.001$ and $\mathrm{p}=0.0193$, respectively (Table3). 
Importance of Sodium Levels for Geriatric Patients Presented to the Emergency Department with a Simple Fall

Table 3. Evaluation of the degree of hyponatremia for our hyponatremic patients according to the locations of the injuries, the presence of fracture and according to referrals from nursing homes

\begin{tabular}{|c|c|c|c|c|c|c|c|}
\hline & \multicolumn{3}{|c|}{ The Degree of Hyponatremia } & \multirow{3}{*}{$\begin{array}{l}\text { Pearson } \\
\text { Chi- } \\
\text { Square }\end{array}$} & \multirow{3}{*}{$\mathbf{p}$} \\
\hline & & & \multirow{2}{*}{$\begin{array}{c}\mathrm{Na}^{+}<125 \\
\mathrm{n}(\%)\end{array}$} & \multirow{2}{*}{$\frac{125 \leq \mathrm{Na}^{+} \leq 129}{\mathrm{n}(\%)}$} & \multirow{2}{*}{$\frac{130 \leq \mathrm{Na}^{+}<135}{\mathrm{n}(\%)}$} & & \\
\hline & & & & & & & \\
\hline \multirow{12}{*}{ 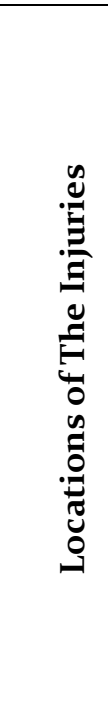 } & \multirow{2}{*}{ Head } & Negative & $1(100)$ & $7(58.33)$ & $44(69.84)$ & \multirow{2}{*}{1.086} & \multirow{2}{*}{0.581} \\
\hline & & Positive & o (o) & $5(41.66)$ & $19(30.15)$ & & \\
\hline & \multirow{2}{*}{ Vertebrae } & Negative & o (o) & $11(91.66)$ & $62(98.41)$ & \multirow{2}{*}{25.868} & \multirow{2}{*}{ o.0oo } \\
\hline & & Positive & $1(100)$ & $1(8.33)$ & $1(1.58)$ & & \\
\hline & \multirow{2}{*}{ Chest } & Negative & $1(100)$ & $11(91.66)$ & $53(84.112)$ & \multirow{2}{*}{0.634} & \multirow{2}{*}{0.728} \\
\hline & & Positive & o (o) & $1(8.33)$ & $10(15.87)$ & & \\
\hline & \multirow{2}{*}{ Pelvis } & Negative & $1(100)$ & $8(66.66)$ & $59(93.65)$ & \multirow{2}{*}{7.912} & \multirow{2}{*}{0.019} \\
\hline & & Positive & o (o) & $4(33.33)$ & $4(6.34)$ & & \\
\hline & \multirow{2}{*}{$\begin{array}{l}\text { Upper } \\
\text { Extremities }\end{array}$} & Negative & $1(100)$ & $12(100.0)$ & $57(90.47)$ & \multirow{2}{*}{1.344} & \multirow{2}{*}{0.511} \\
\hline & & Positive & o (o) & o (o) & $6(9.52)$ & & \\
\hline & \multirow{2}{*}{$\begin{array}{l}\text { Lower } \\
\text { Extremities }\end{array}$} & Negative & $1(100)$ & $4(33.33)$ & $31(49.20)$ & \multirow{2}{*}{2.145} & \multirow{2}{*}{0.342} \\
\hline & & Positive & o (o) & $8(66.66)$ & $32(50.79)$ & & \\
\hline \multirow{2}{*}{\multicolumn{2}{|c|}{ Fracture }} & Negative & o (o) & $8(66.66)$ & $35(56.45)$ & \multirow{2}{*}{1.827} & \multirow{2}{*}{0.401} \\
\hline & & Positive & $1(100)$ & $4(33.33)$ & $28(43.55)$ & & \\
\hline \multirow{2}{*}{\multicolumn{2}{|c|}{ Nursing Home }} & Negative & $1(100)$ & $8(66.67)$ & $54(85.71)$ & \multirow{2}{*}{2.788} & \multirow{2}{*}{0.248} \\
\hline & & Positive & o (o) & $4(33.33)$ & $9(14.28)$ & & \\
\hline
\end{tabular}

Whereas the patients with mild hyponatremia presented mostly with lower extremity injuries $(50.79 \%, \mathrm{n}=32)$, the patients with moderate hyponatremia presented with upper extremity $(100 \%, \mathrm{n}=12)$, lower extremity $(66.7 \%, \mathrm{n}=8)$ and head $(41.7 \%, \mathrm{n}=5)$ injuries (Table 3).

No statistically significant correlation was found between the degree of hyponatremia and the presence of a fracture ( $\mathrm{p}=\mathrm{0.401}$, Table 3$)$. There was no significant relationship between the degree of hyponatremia and referral from a nursing home $(\mathrm{p}=0.248$, Table 3).

\section{Discussion}

According to the main results of our study there were no statistically significant differences in the locations of the injuries according to the presence of hyponatremia $(\mathrm{p}=0.743)$. The prevalence of hyponatremia was not significantly different between the patients with and without fractures $(\mathrm{p}=\mathrm{0.105})$. The prevalence of hyponatremia was statistically significant in the patients who were referred from a nursing home for simple falls $(\mathrm{p}<0.001)$. 
The U.S. Center for Disease Control (CDC) states that one in every three people $\geq 65$ years falls. ${ }^{4}$ Murdoch I et al. reported that this rate increases over the age of 80 years to one in every two people. ${ }^{13}$ In the present study, the mean age of the patients was 79.2 \pm 8.08 years, and it is compatible with the literature. There is a need for studies on falls and the subsequent fracturesin geriatric patients to guide preventive measures.

The guidelines of the American Geriatrics Society (AGS) and the British Geriatrics Society (BGS) suggest that gender is a risk factor for falls in the geriatric patients. ${ }^{2}$ Ganguli A et al. conducted a study in geriatric home-care patients and reported that $77 \%$ of the patients were female. ${ }^{14}$ Icme $\mathrm{F}$ et al. conducted a study investigating the use of trauma scoring systems in geriatric patients who visited the emergency department for falls and determined that the prevalence of female patients was $62.7 \%{ }^{15}$ Likewise in the present study, although the difference was not statistically significant,females accounted for $62.5 \%(n=168)$, and males accounted for $37.5 \%(n=101)$ of the geriatric patients who presented with falls. We think that the reason between the risk of falls and the female gender requires further investigation in additional studies.

The US Geriatrics Society Guidelines for Geriatric Emergency state that electrolyte disorders are important in geriatric patients who visit the emergency departments for falls, emphasizing the need for more detailed studies of this subject, and recommend that blood electrolyte levels should be routinely measured for each patient. ${ }^{1}$

Rittenhouse $\mathrm{KJ}$ et al. reported that hyponatremia is a factor that determines the risk of falls in the geriatric population. ${ }^{6}$ Similarly, Cumming K et al. reported that hyponatremia may be a risk factor for falls and that hyponatremia is prevalent and observed in $26 \%$ of cases. ${ }^{7}$ Spasovski G. published a guideline for the diagnosis and treatment of hyponatremia and suggested the presence of a strong relation between hyponatremia and falls in geriatric patients. " Siregar P. reported that the prevalence of hyponatremia is $18.28 \%$ in geriatric patients who have visited an emergency department. ${ }^{16}$ In the present study, the prevalence of hyponatremia was $28.25 \%(\mathrm{n}=76)$. This result is consistent with the literature.

Lee $\mathrm{KH}$ et al. found the incidence of pelvis fractures to be high in geriatric patients with delirium and dementia. ${ }^{17}$ Gankam Kengne F et al. reported that the risk of hyponatremia-associated falls and fractures is increased and that the incidences of femur and hip fractures are greatest among this age group..$^{18}$ In the present study, $50.9 \%$ of the patients with hyponatremia exhibited lower extremity injuries, and 30.11\% exhibited head injuries. These were the most commonly seen trauma sites. We believe that patients with hyponatremia therefore frequently present with lower extremity and head traumas.

In our study, the incidences of vertebrae and pelvis injuries increased with increasing severity of hyponatremia $(\mathrm{p}<0.001$ and $\mathrm{p}=0.019$, respectively). In contrast, regarding fractures accompanying traumas, the incidence of femur fracture $(58.6 \% ; n=81)$ was significantly greater than that of cranial bone fractures $(7.2 \% ; n=10)$. We observed that the patients with mild and moderate hyponatremia frequently presented with lower extremity and head traumas. The incidence of trauma significantly increased as the degree of hyponatremia increased, and the trauma was usually associated with the pelvic and vertebral regions. Based on these findings, we conclude that patients with mild and moderate hyponatremia frequently present with lower extremity and head traumas, whereas patients with moderate and severe hyponatremia typically visit the 
emergency department with vertebral and pelvic traumas that might frequently be overlooked.

The prevalence of multiple traumas in the patients who presented with falls was found to be $21.6 \%$. The most common combinations of traumas were head-lower extremities $(n=13)$, pelvis-lower extremities $(n=12)$, and head-pelvis traumas $(n=12)$. There were four patients with triple traumas, i.e., head-pelvis-lower extremity traumas. Multiple traumas should be considered when examining geriatric patients who visit the emergency department for simple falls, and we believe that the head, pelvis and the lower extremities in particular should be examined more precisely.

The guidelines for hyponatremia emphasize that there are limited numbers of studies that have investigated plasma $\mathrm{Na}^{+}$concentrations in geriatric patients who develop fractures and that further studies regarding the relationship between hyponatremia and falls are required. ${ }^{1,2}$ İçme $\mathrm{F}$ et al. identified femur fractures in $15.5 \%$ of the geriatric patients presenting to the emergency department with falls. ${ }^{15}$ Hoorn EJ et al. identified a strong correlation between mild hyponatremia and fractures of the large bones in geriatric patients. ${ }^{19}$ Streubel PN et al. demonstrated that cognitive dysfunction is a risk factor for femur fractures, which are associated with short-term mortality in these patients. ${ }^{20}$ In the present study, the overall prevalence of fractures was $51.3 \%(n=138)$, and the incidence of femur fractures was $30.1 \%(n=81)$. Among the overall fractures, femur fractures were the most common with prevalence of $58.6 \%$. The prevalence of the combination of hyponatremia and fractures was found to be $43.4 \%(n=33)$. In the present studyno statistically significant relation was identified between hyponatremia and the presence of fracture [p>0.05; OR $(95 \% \mathrm{CI})=0.643(0.377$ - 1.098)]. Therefore, we don't think hyponatremia as a risk factor for newly developed fractures in geriatric patients who presented with falls.

In the present study, lower extremity fractures, including femur fractures in the lead, were the most prevalent traumas in the patients who presented with falls.

Hyponatremia appeared to be a risk factor in the present study population; however, we believe that age and osteoporosis rather than hyponatremia are the leading factors associated with occurrence of fracture.

Choudhury $\mathrm{M}$ et al. reported that the duration of hospital stay is relatively longer for patients who are referred from nursing homes for hyponatremia and that nursing homes have not taken necessary measures to prevent this. ${ }^{21}$ In the present study, $6.3 \%$ of the patients were referred from nursing homes. The prevalence of hyponatremia among the patients from nursing homes was $76.5 \%$. We found no significant relationship between the degree of hyponatremia and staying in a nursing home $(\mathrm{p}=$ o.248). Therefore, we believe that the presence rather than the degree of hyponatremia is a risk factor for falls and that patients from nursing homes presented with more falls in the presence of even mild hyponatremia.

\section{Limitations}

Our study was a single centre study with a limited number of patients and this limits the generalizability of our results.

In conclusion, based on the results of the present study and earlier studies in the literature, we believe that the age of 80 years should be considered a threshold value, 
and hyponatremia needs to be considered an independent risk factor for falls in patients who are $\geq 65$ years. In this study, the presentation with a fall was more prevalent among females than males.

The patients with hyponatremia most frequently presented with lower extremity and head traumas. Additionally, the vertebral and pelvic traumas, although rare, are lifethreatening and associated with high mortality, and increase with the degree of hyponatremia, which again supports the notion that hyponatremia must be considered a risk factor. However, considering that femur fractures were the most prevalent fractures among the target populations, hyponatremic or not, and that there was no significant difference between the groups, we conclude that there was no direct relationship between hyponatremia and the development of fractures, which contrasts the previously defended theory.

The prevalence of hyponatremia was high in the patients from nursing homes, and the number of these patients was low. We believe that hyponatremia is common in the patients who are staying in nursing homes, and further studies on this subject are needed.

\section{References}

1. Carpenter CR, Bromley M, Caterino JM, et al. Optimal older adult emergency care: introducing multidiciplinary geriatric emergency department guidelines from the American College of Emergency Physicians, American Geriatrics Society, Emergency Nurses Association, and Society for Academic Emergency Medicine. Acad Emerg Med 2014;21:806-9.

2. Kenny RA, Rubenstein LZ, Tinetti ME, et al. Summary of tye Updated American Geriatrics Society/ British Geriatrics Society clinical practice guideline for prevention of falls in older persons. J Am Geriatr Soc 2011;59:148-57.

3. Tirrell G, Sri-on J, Lipsitz LA, et al.Evaluation of older adult patients with falls in the emergency department: discordance with national guidelines.Acad Emerg Med 2015;22:461-7.

4. Falls among older adults: an overview.Centers for Disease Control and Prevention. Web site. Available at: http://www.cdc.gov/HomeandRecreationalSafety/Falls/adultfalls.html. Accessed on September 26, 2015

5. Appelman-Dijkstra NM, Papapoulos SE. Prevention of incident fractures in patients with prevalent fragility fractures: Current and future approaches. Best Pract Res Clin Rheumatol 2013;27:805-20.

6. Rittenhouse KJ, To T, Rogers A, et al. Hyponatremia as a fall predictor in a geriatric trauma population. Injury 2015;46:119-23.

7. Cumming K, Hoyle GE, Hutchison JD, et al. Prevalence, Incidence and Etiology of Hyponatremia in Elderly Patients with Fragility Fractures. J Clin Med Res 2015;7:45-51.

8. Muir SW, Gopaul K, Montero Odasso MM. The role of cognitive impairment in fall risk among older adults: a systematic review and meta-analysis. Age Ageing 2012;41:299-308.

9. Definition ofan older or elderly person. WHO. Web site. Available at:http://www.who.int/healthinfo/survey/ageingdefnolder/en/. Accessed on May 25, 2015.

10. Nelson JM, Robinson MV. Hyponatremia in older adults presenting to the emergency department. Int Emerg Nurs 2012;20:251-4.

11. Spasovski G, Vanholder R, Allolio B, et al. Clinical practice guideline on diagnosis and treatment of hyponatraemia. Nephrol Dial Transplant 2014;40:924.

12. Hoorn EJ, Lindemans J, Zietse R. Development of severe hyponatraemia in hospitalized patients: treatment-related risk factors and inadequate management. Nephrology, Dialysis, Transplantation 2006;21:70-6.

13. Murdoch I, Turpin S, Johnston B, eds. Falls and immobility. In: Geriatric Emergencies. USA: Wiley; 2015:112-27.

14. Ganguli A, Mascarenhas RC, Jamshed N, et al. Hyponatremia: incidence, risk factors, and consequences in the elderly in a home-based primary care program. Clin Nephrol 2015;84:75-85. 
Importance of Sodium Levels for Geriatric Patients Presented to the Emergency Department with a Simple Fall

15. Icme F, Becel S, Ahmedali A, et al. The use of trauma scoring systems in elderly patients who are admitted to the emergency department due to falls. Turkish Journal of geriatrics 2014;17:138-42.

16. Siregar P. The Risk of Hyponatremia in The Elderly Compared with Younger in The Hospital Inpatient and Outpatient. Acta Med Indones 2011;43:158-61.

17. Lee KH, Ha YC, Lee YK, et al. Frequency, risk factors, and prognosis of prolonged delirium in elderly patients after hip fracture surgery. Clin Ortop Relat Res 2011;469;2612-20.

18. Gankam Kengne F, Andres C, Sattar L, Melot C, Decaux G. Mild hyponatremia and risk of fracture in the ambulatory elderly. QJM 2008;101:583-8.

19. Hoorn EJ, Rivadeneira F, van Meurs JB, et al. Mild hyponatremia as a risk factor for fractures: the Rotterdam Study.Journal of Bone and Minereal Research 2011;26:1822-28.

20. Streubel PN, Ricci WM, Wong A, Gardner MJ. Mortality after distal femur fractures in elderly patients. Clin Orthop Relat Res 2011;469:1188-96.

21. Choudhury M, Aparanii K, Norkus EP, Dharmarajan TS. Hyponatremia in hospitalized nursing home residents and outcome: minimize hospitalization and keep the stay short! J Am Med Dir Assoc 2012;13:e8-9. 